\title{
Holding it Together in a Crisis: Family Strengthening and Embedding Neoliberalism
}

\author{
Kate Bedford
}

\author{
1 Introduction \\ We have begun to recognize the need to base \\ our development approach more solidly on \\ partnership (Nicolas Stern, former World Bank \\ Chief Economist 2003)
}

The field of International Political Economy is awash with references to crisis, shock and rupture (Klein 2007; Blustein 2003). Neoliberalism is widely understood to have entered and exited the world stage with the help of crises, bookended on one side (in Latin America at least) by the debt crisis and hyperinflation, and on the other by financial crises and a perceived meltdown in social sustainability. The Post Washington Consensus (PWC) agenda was a response to the latter problem, placing greater emphasis on institutional strengthening, balance between states and markets, and equity and inclusion. This shift is broadly understood as an attempt to embed neoliberalism and secure its sustainability by better insulating it from crises. ${ }^{1}$

Gender and sexuality are rarely considered relevant to these debates, but two feminist insights about crisis have clear import: that gendered and sexualised anxieties can be central to experiences of crisis; ${ }^{2}$ and that neoliberalism has generated a gendered crisis in social reproduction. ${ }^{3}$ These insights show how perceptions of a crisis in the family, in sexuality and in gender relations more broadly can serve to crystallise anxieties about social change, demonstrating that threats to the nation-state may be filtered through gendered and sexualised anxieties about national virility, sovereignty, and integrity (Alexander 2005; Hoad 2000; Tadiar 1998). Using these frameworks, I ask what we can learn about crisis management, embedding neoliberalism and the dynamic between appeals to the past and present during crisis by taking gender and sexuality seriously. How are debates about neoliberal crisis gendered? What kinds of gender reform are considered central to recovery, and what kinds of intimate relations and social reproduction arrangements does the post-crisis future herald? And what can this tell us about the role of heteronormativity in development more generally?

\section{Exhausted women and wounded men: gender} crisis and its resolution in the World Bank

The World Bank is a key site for exploration of these questions, since it epitomises the shift from a Washington to a PUC development approach. Moreover, the economic crises to which the Bank's new, more balanced development approach was the purported cure were linked to a crisis in gender relations, particularly to a crisis in masculinity. ${ }^{4}$ Economic crisis and the free market restructuring that followed were seen to strip men of socially valued roles as breadwinners. Their masculinity thus wounded, poor, unemployed men were an increasingly dangerous threat to women and children. Bank gender documents also referred to the fact that women were being overburdened through their increasing labour in crisis conditions, in evidence that feminist critique of structural adjustment was resonating within the organisation.

Although the World Bank's anti-indigence projects have hence been (rightly) criticised for overburdening women and naturalising their struggles to secure family survival in crisis conditions (Molyneux 2006; Luccisano 2004), it is significant that the organisation's gender policymakers take a different approach to social reproduction concerns. They attempt to draw men into caring labour, while 
promoting women's work outside the home. Considerable emphasis is now placed on men and women working together, in balanced unity, to achieve development goals, and male inclusion, fatherhood promotion and family strengthening are now central to gender policy advice, especially in the Latin America and Caribbean region. Hence the family, and the crisis into which it had been plunged through economic upheaval, became a central concern of gender policymakers. In turn, the PWC holds out the promise of restored balance and harmony through adjusted partnerships in which women are emancipated through waged work and men are included in the family as responsible fathers and partners.

A recent crisis-era project loan to Argentina is an example of this process. Argentina is a key case study of crisis given its journey from neoliberal poster-child of the International Financial Institutions under Carlos Menem to exemplar of disaster in 2001. Gender staff have seen their scope for intervention in the Bank's policies fluctuate across these shifts in development approach, but they have had to consistently contend with a difficult domestic environment around reproductive rights. Menem fiercely opposed reproductive rights, and in the late 1990s Argentina lacked a national reproductive health policy. Unsafe abortion was - and still is - the leading cause of maternal mortality. When the Bank reached out to feminist civil society organisations in the 1990s for advice on where to target social lending, reproductive health was identified as a key priority. But it was one which the government did not support.

The 2001-6 Family Strengthening and Social Capital Promotion Project, PROFAM, emerged out of this context. This involved a US\$5 million loan from the Bank, administered by Argentina's National Women's Council (CNM). PROFAM was an attempt to support reproductive health projects and serve civil society groups working in gender. Bank staff recognised that this could generate controversy, and they had to pitch the project to a government heavily influenced by the Church, and to a CNM which had been divided and weakened by controversies over reproductive rights. Hence PROFAM was shaped pre-emptively to avoid conflict and bring potential opponents on board as allies.

In particular, PROFAM used the language of family strengthening because it was associated with the
Catholic Church and its concerns with family breakdown and disintegration of gender roles. As one interviewee explained when asked what the language of family strengthening meant in Argentina:

It has to do with powers associated with the Church, which is very strong in Argentina ... The gender stereotypes linked to [the] Church's conceptualisation are very strong. The discussion of family has to do with this way of thinking, and the notion that the family is in crisis stems from this conceptualisation. [emphasis added]

Hence, in advocating for PROFAM Bank staff invoked a Cáritas family strengthening project as a model for work on 'Family capacity, gender relations, and household structure', itself the first 'priority action' in Argentina's 1999 Gender Audit (Correia 1999: 25-6). Plans for PROFAM were also circulated to Cáritas before they were submitted to the government for formal approval.

However, a range of other actors also argue that the family is in crisis because of neoliberal reform; I was told this by feminists, by NGOs expressing hostility to feminists, by community-based organisations, and by those associated with the Church. Moreover, as noted above, family strengthening is a Bank language, and gender staff could draw on wellrehearsed internal arguments about families as key social safety net mechanisms, and about a crisis in gender relations and poor men's irresponsible behaviour in Argentina. These formed part of the Bank's 1999 Gender Portfolio for Argentina, which used all of the standard Bank arguments about the importance of a 'true' gender perspective requiring attention to men (especially poor unemployed men), and the benefits to be gained in terms of efficiency and empowerment from encouraging partnership (Correia 1999). The report also expressed concern at an increase in single parent families headed by women on the grounds that 'the absence or transitory nature of a paternal figure (biological or not) increases the probability of a lack of material, social and psychological resources required for children's identity development (Johnson 1997)' (Correia 1999: 23). The cite is to Deborah Johnson's Father Presence Matters, published by the US-based National Center on Fathers and Families.

Hence, when PROFAM was written up it appealed heavily to these themes of male inclusion and family 
strengthening. It was described as a way to 'strengthen family cohesion [and] solidarity between male and female members' of households (World Bank 2000: 1), to 'test the hypothesis that the promotion of a more cohesive, less segregated family life will positively impact the ability of families to face challenges posed by poverty' (ibid.: 3). Its key performance indicators included: '[an] improved awareness among beneficiary families about the importance of gender equity and cohesive family practices as [a] means of reducing their vulnerability', a decrease in domestic violence, and 'improved evidence of responsible parenthood ... through: (i) increase in [the] father's involvement in childcare and support; and (ii) decrease in teenage pregnancy' (World Bank 2001b: 2). Staff also claimed that PROFAM would provide economic benefits by supporting unemployed household heads to adapt to new roles (ibid.: 7), and improving income-generating opportunities for women (ibid.: 10).

Argentina's National Women's Council (CNM) was sought out as a partner by the Bank on the grounds that it already used this approach, and had a track record in policies 'promoting shared responsibility among men and women within the concept of citizenship. In practical terms, this has meant a response to poverty based on a strategy that emphasises the inclusion of men in household chores and child care, [and] the expansion of opportunities for women in the labour market and public decisionmaking' (World Bank 2001b: 4). In short, then, as Bank gender staff and their domestic allies grappled to secure support for a potentially controversial project, they found the theme of gender crisis and the promise of restoration of balance through family strengthening very helpful. This theme was already deeply embedded in the Church (the agent with the most potential to block the initiative), the Bank, the $\mathrm{CNM}$, and in certain trajectories of non-governmental organisation (NGO) debate as well. In this way, gender crisis provided a crucial - and religiously inflected - frame for the project from the start.

\section{From design to implementation via crisis}

A key 'critical assumption' of PROFAM's design matrix was 'no major economic and social crisis' (World Bank 2001b: 18). When this assumption proved spectacularly wrong one month after the loan was approved by government, the project was at first stalled, and then revived with a higher profile. Indeed PROFAM ended up funding 238 projects, reaching 140,000 families, or 700,000 individuals - a substantial upscaling from the 100 subprojects promised in the 2001 appraisal (World Bank 2001b: 19). A new administrative team was brought in to execute the initiative and a new call for projects was issued in 2003, after Néstor Kirchner was elected (on an expressly anti-Washington Consensus platform).

Considerable space was opened up within PROFAM in this crisis-afflicted context, and several progressive organisations were given money to fund initiatives which used the language of 'family strengthening' very instrumentally. These included a union of sex workers who got support for anti-violence initiatives and sex education work, and pro-choice activists who ran reproductive health seminars. That said, however, it would oversimplify matters to identify the role of crisis in PROFAM as unilaterally productive of innovative space. I thus wish to elucidate two other ways in which crisis affected the project here: the increased influence it granted to the Church; and the increased centrality of gendered appeals to the restoration of Argentine values. I intend this elucidation to complicate, rather than deny, the spaces opened for progressive seizure during chaos.

Many self-identified feminists involved in PROFAM's early stages felt that Church involvement was a savvy move, since family strengthening was so ill-defined. However, some were concerned that the Churchinfluenced framing of the project could backfire. As one interviewee explained:

Strengthening the family could be to change gender roles, or not. Herein lies all the ambiguity of these formulations ... I always found this formulation quite risky, even the name of the project, pro-family, PROFAM ... The formulation could be a strategy, part of a formula that could be very progressive, in the sense of incorporating reproductive rights, but in the hands of another person who wanted to turn the text around and take a more religious or traditional approach, it's an extremely risky instrument.

Economic and political crisis altered the environment in which these risks played out, changing the uneasy equilibrium between progressive and conservative visions of family strengthening in place in the design phase, and giving the Catholic Church far more power in the project than it had at the start. The Church dramatically extended its influence over social policy 
during the 2001 meltdown, when it was given a formal role in the state's emergency response. In 2002, President Duhalde set up la Mesa de Diálogo Argentino, involving the National Executive, the UN, key union leaders, and the Catholic Church (Dinatale 2004: 37, 50). The Church was hereby given a key role by the government in redesigning the state's emergency assistance policies, and it was a pivotal supporter of the Heads of Household programme, a World Bank-funded 'social megaplan' providing a minimal income to families. Moreover, in a conciliatory move towards conservatives, in 2003 Kirchner gave control of the CNM to María Lucila ('Pimpi') Colombo, a member of the Nueva Dirigencia Party created by conservative activist Catholic Gustavo Beliz (Lopreite 2006: 15). Hence, Church-based organisations were far more prominent in the second convocatoria (when Colombo was running the CNM) than in the first. For example a group of (self-described) Church ladies got funding for a project with mothers of drug addicts, and the housewives' union SACRA (linked to the Church and in which Colombo had long been active) was given money for a microenterprise project in which women sewed baby clothes.

I note these shifts not to impugn the projects carried out by Church-affiliated organisations, many of which have played a key role in providing services to the poor. Rather, I note them because the increasing involvement of such organisations in PROFAM was clearly related to Argentina's crisis. The Church was given more power over social policy as a result of the crisis, and this caused anger among self-identified feminist groups involved at the start. Moreover, the growing role of Church-affiliated groups was not considered a problem by the Bank, despite the fact that PROFAM was - like all Bank work - expressly forbidden from funding religious activities. This disjuncture in part reflects the fact that the directions in which PROFAM was being steered through the Church's participation were not marked as religious directions. To the Bank, it is secular common sense that gender was about sharing balance, that the family had been destroyed by economic crisis and needed strengthening through the encouragement of 'loving couplehood'; that poverty policy was a space for advice on responsible parenting and promotion of fatherhood. The fact that these conversations have been central tenets of the Catholic hierarchy's teachings in Latin America in the last decades remains unmarked (except by feminists). Hence, the religious nature of the effort to generate inclusive, balanced development through forging new loving partnerships between men and women escapes scrutiny.

\section{PROFAM and the restoration of Argentine \\ values}

The wide range of meanings attached to the term 'family strengthening' narrowed during the project as a result of the Kirchner government's redefinition of gender policy as about restoring family unity in response to economic crisis (a redefinition the Bank had made years earlier). In the Bank's 2006 Country Assistance Strategy (CAS) for Argentina, the government described its development approach as focused on repairing and rebuilding the social fabric (Annex A in World Bank 2006: 72). In turn the President's sister, who was at the time in charge of social policy coordination, described PROFAM as part of a broader reconstruction of the social fabric, strengthening the social links that connect people to each other:

Within this work in our communities, the key is the family, of this there is no doubt... If one wants to change reality, one has to work together with the family, together with the family, with the family. (PROFAM 2006 DVD 2, original vocal emphasis)

As she explained in the DVDs put out to publicise the project's achievements, this was a national project linked to the revival of Argentine values, which had been hurt after years of neoliberalism.

PROFAM's new administrators also introduced the concept of 'resilience' to the project, absent from discussions in the planning stages. An example of a project that used this language worked with young people in workshops on reproductive health, responsible maternity and paternity, and resilience. Participants would learn responsible parenthood and the importance of raising children within a family environment; single mothers would learn to offer their children the love and care they deserve; and all those involved 'would be capable of surviving and overcoming adversity, utilising the creativity and potentiality hidden in their spirit, leaving them strengthened and able to face life'.

The language of resilience was also used by projects aiming to restore the principle of family meals to poor households. One such initiative was the only example given in the DVDs on the long-term results of PROFAM. As explained by the local coordinator: 
One of the things that we realised when we made the visit (to the community) ... is that the table as an object had disappeared from the homes; a decade of community kitchens meant that the mother did not cook, that the table was not used as a communal space, where family and social and community problems were discussed ... So what we proposed was how to go back to eating as a family. (PROFAM 2006)

The project ensured that women got access to fresh vegetables so they could cook nutritious meals for their families. State-funded community kitchens were closed, changed into family gardens. In this way, the project aimed 'to recuperate the family table, as a space of dignity'.

Similar trends towards increased reliance on privatised, unpaid family labour to increase the ability of the poor to cope with crisis were evident in microenterprise projects, which also grew in popularity after 2003. For example several of the projects involving youth aimed at restoring family harmony by teaching young people to support women's involvement in income-generating work, 'so that you didn't end up with a battleground in the family', as one NGO put it. In contrast there was no systematic effort made within PROFAM to provide childcare services for women working in microenterprises. As PROFAM got more involved in productive activities, then, it responded to the ensuing tensions between paid and unpaid labour by promoting family care, not nurseries.

\section{Contesting complementarity as a crisis strategy}

PROFAM suggests that the economic crises to which the World Bank's new, more balanced development approach was the purported cure were linked to a crisis in gender relations, with women understood to be overburdened through multiple responsibilities and men's roles thrown into tumult. Moreover, the space opened up for seizure during Argentina's crisis was not a newly levelled free-forall. As free market common senses unravelled, other common senses about gender crisis, the importance of family strengthening as a poverty reduction strategy, and the restoration of national values through male- female harmony were re-centred. With the injuries of neoliberalism framed as injuries to loving couplehood, the Bank and its allies resolve to (re)generate intimate partnership as a defining feature of the post-crisis era, raising crucial questions about the new regimes of heteronormativity under construction in contemporary development practice.

The Bank was a key actor here, with its own investments in the idea that good gender policy rests on generating loving partnerships; that gender roles - especially for poor men - are in crisis; that families are key safety net mechanisms; that private provision of care within families is an efficient and empowering way to resolve tensions between paid and unpaid labour. However, its policies of family strengthening, male inclusion and partnership promotion have proved successful because they have hailed other actors with their own investments in these themes, including NGOs trying to sustain poor communities in the face of the state's retreat, the Church, and the expressly anti-neoliberal Kirchner government. The Bank was thus able to draw together a range of other social actors around a common understanding of development problems as requiring gender balance solutions. It sells the Post Washington Consensus - and its own continuing role as a crucial interlocutor of development policy on values of gender balance and harmonious couplehood that 'everyone', from the CNM to the Church, from Kirchner to Wolfowitz - accepts, and which are taken for granted as part of the naturalised social environment (Fligstein 2001: 114).

This leaves us with the crucial question of what response the model of sharing partnership offered in PROFAM merits. Clearly it provides space for feminist seizure, in that it takes on board the critique of the Washington Consensus for overburdening women and ignoring unpaid care, while moving beyond nostalgia for breadwinner-housewife solutions to the social reproduction dilemma. If Argentina is, to use Jacqui Alexander's framing, a neocolonial state trying to 'manag(e) internal ruptures by using heterosexuality in defense of nation' (2005: 12), the heterosexuality it is mobilising in the post-crisis era is not that mobilised in the postwar welfare state, and it can appear the ideal solution for some feminists interested in development. After all, many feminists wanted men to stop shirking domestic work and International Financial Institutions to take care seriously. However we did not necessarily want childcare erased as a policy priority, replaced by more shared (but still privatised) caring labour within couples. We did not want poor men held responsible for women's poverty. We may be uncomfortable about anti- 
indigence policies reliant on pre-determined intimate attachments; and not all of us wanted our critique of neoliberalism for generating a crisis in social reproduction reinterpreted as a rallying call to prevent crisis in the family.

I would suggest that we will be better positioned to contest those shifts if we can 'engage in a persistent critique of what one cannot not want' (Spivak 1999: 284, quoted in Baaz 2005: 176) - an unsettling task. After all, who can disagree with the idea that fathers should love their children (Gavanas 2004: 21), and what better way to build support for a new development model than by promising that it will produce loving harmony between men and women? If the new language of empowerment gives us all 'a warm, cuddly feeling' (Parpart 2002: 52), how much more cuddly is the newer language of loving fatherhood, reformed masculinity and sharing couples? One may as well be against puppies.

In this sense, the promotion of adjusted partnerships in which women work more and men care better has become a piece of GAD common sense - it has been mainstreamed into invisibility as a policy intervention. This is a cause for great concern.

\section{Notes}

1 See Porter and Craig (2004). Peck and Tickell (2002) characterise the PWC as a period of roll out neoliberalism, distinct from the roll back period of the 1980 s.

2 On the way in which perceptions of a crisis in the family, in sexuality, in gender relations more broadly can serve to crystallise anxieties about social change, see Alexander (2005); Hoad (2000); Tadiar (1998). This work demonstrates that threats to the nation-state may be filtered through gendered and sexualised anxieties about national virility, sovereignty, and integrity.

3 Social reproduction includes biological reproduction, the reproduction of labour power, and social practices connected to caring,
Conflict and comment should ensue when Bank staff assert that family cohesion is a poverty-eradication strategy; that poor men are the key concern in gender lending; that transnational institutions should publicly assume new roles in teaching the poor to privately juggle tensions between market and nonmarket labour. The approach renders many efforts to enhance women's intimate autonomy unspeakable, and its constant emphasis on good policy as benefiting both halves of the heteronormative whole makes power relations invisible. Conflict within the family becomes harder to talk about; conservative religious institutions concerned about family breakdown get more space to direct policy priorities; and childcare becomes extremely hard to argue for. Forging an alternative will require us to question deeply held common-senses about loving partnerships, not to mention the hyper-oppressive nature of poor men. Hence it will require us to denaturalise not only markets and dominant arrangements of social reproduction, but also sexualities, to critically interrogate the assumptions about sexuality that circulate in our conversations about crisis and social reproduction, and to ask how we might want recovery, anti-poverty, and intimacy configured differently.

socialisation and the fulfilment of human needs (Bakker and Gill 2003). It includes childcare, housework, subsistence agriculture, cooking, voluntary work to sustain community organisations, paid domestic labour, sex work and so on. As a litany of feminist activists and scholars demonstrated, the structural adjustment phase of market reform rested on an implicit assumption that women would provide many of these services, unpaid, at the same time that they entered the paid labour market.

4 I develop this argument in Bedford (forthcoming), but see Engendering Development (World Bank 2001a) and The Other Half of Gender (Bannon and Correia 2006) for examples within World Bank documents 


\section{References}

Alexander, M. J. (2005) Pedagogies of Crossing: Meditations on Feminism, Sexual Politics, Memory, and the Sacred, Durham: Duke University Press

Baaz, M.E. (2005) The Paternalism of Partnership: A Postcolonial Reading of Identity in Development Aid, New York: Zed Books

Bakker, I. and Gill, S. (eds) (2003) Power, Production and Social Reproduction: Human In/Security in the Global Political Economy, Toronto: York University

Bannon, I. and Correia, M. (eds) (2006) The Other Half of Gender: Men's Issues in Development, Washington DC: World Bank

Bedford, K. (forthcoming) Developing Partnerships: Gender, Sexuality, and the Post Washington Consensus World Bank, Minneapolis: University of Minnesota Press

Blustein, P. (2003) The Chastening: Inside the Crisis that Rocked the Global Financial System and Humbled the IMF, Cambridge, MA: Public Affairs

Correia, M. (1999) Las Relaciones de Género en la Argentina. Un Panorama Sectorial [Gender Relations in Argentina: A Sectoral Panorama], Equipo de Género, Región de América Latina y el Caribe, Report 20911, Buenos Aires: Banco Mundial

Dinatale, M. (2004) El Festival de la Pobreza: El Uso Político de Planes Sociales en la Argentina [Festival of Poverty: The Political Use of Social Plans in Argentina], Buenos Aires: Konrad-AdenaverStiftung

Fligstein, N. (2001) 'Social Skills and the Theory of Fields', Sociological Theory 19.2: 105-25

Gavanas, A. (2004) Fatherhood Politics in the United States: Masculinity, Sexuality, Race, and Marriage, Urbana: University of Illinois Press

Hoad, N. (2000) 'Arrested Development or the Queerness of Savages: Resisting Evolutionary Narratives of Difference', Postcolonial Studies 3.2: 133-58

Johnson, D. (1997) Father Presence Matters, Philadelphia: National Center on Fathers and Families

Klein, N. (2007) The Shock Doctrine: The Rise of Disaster Capitalism, New York: Metropolitan Press

Lopreite, D. (2006) 'Gender and Welfare Regime Change in Argentina: International Conventions and Feminist Networks in a New Social Agenda', paper presented to Annual Meeting of Canadian Political Science Association, Toronto, 2 June Luccisano, L. (2004) 'Mexico's Progresa Program (1997-2000): An Example of Neo-Liberal Poverty Alleviation Programs Concerned with Gender,
Human Capital Development, Responsibility, and Choice', Journal of Poverty, Special Issue 8.4: 31-57 Molyneux, M. (2006) 'Mothers at the Service of the New Poverty Agenda: Progresa/Oportunidades, Mexico's Conditional Transfer Programme', Social Policy Administration 40.4: 425-49

Parpart, J. (2002) 'Lessons from the Field: Rethinking Empowerment, Gender and Development from a Post- (Post-?) Development Perspective', in K. Saunders (ed.), Feminist Post-Development Thought: Rethinking Modernity, Post-Colonialism and Representation, New York: Zed Books

Peck, J. and Tickell, A. (2002) 'Neoliberalizing Space', Antipode 34.3: 380-404

Porter, D. and Craig, D. (2004) 'The Third Way and the Third World: Poverty Reduction and Social Inclusion in the Rise of "Inclusive" Neoliberalism', Review of International Political Economy 11.2, May: 387-423

PROFAM (2006) 9 DVDs on PROFAM, Buenos Aires: National Women's Council (CNM)

Spivak, G.C. (1999) A Critique of Postcolonial Reason: Towards a History of the Vanishing Present, New York: Harvard University Press

Stern, N. (2003) 'Scaling up: The Challenge of Monterrey', in B. Tungodden, N. Stern and I. Kolstad (eds), Annual World Bank Conference on Development Economics Europe. Toward Pro-Poor Policies: Aid, Institutions, and Globalization, Washington DC: World Bank/Oxford UP

Tadiar, N.X.M. (1998) 'Prostituted Filipinas and the Crisis of Philippine Culture', Millennium 27.4: 927-54

World Bank (2006) CAS for the Argentine Republic 2006-8, IBRD and IFC Report 34015-AT, 4 May, Washington DC: World Bank

World Bank (2001a) Engendering Development Through Gender Equality in Rights, Resources, and Voice, Washington DC: World Bank/Oxford UP

World Bank (2001b) 'Project Appraisal Document on a Proposed Learning and Innovation Loan in the Amount of US $\$ 5$. Omillion to the Argentine Republic for a Family Strengthening and Social Capital Promotion Project - PROFAM', 30 October, Project Information Document Report 21344-AR, Project ID P070374, Washington DC: World Bank

World Bank (2000) Argentina - Family Strengthening and Social Capital Promotion Project - PROFAM (LIL), Project Information Document Report PID9623, Project ID. ARPE70374, 31 July, Washington DC: World Bank 